\title{
"STRIKE SENIORITY" POLICY: UNFAIR LABOR PRACTICE OR LEGITIMATE BUSINESS DEVICE?
}

$T$ HE EVER-INCREASING POWER of modern industrial and trade unions has led to a correlative desire on the part of management to devise new means for exerting economic pressure upon striking workers. Illustrative of those innovations is the "strike seniority" policy which is characterized by an employer's offer of seniority rights to strike replacements, as well as to those workers who have either abandoned or not participated in an economic strike. ${ }^{1}$ Upon termination of the strike, reinstated strikers, if any, are then subordinated in seniority to the replacements, and, in the event of a lay-off, are the first employees to be discharged. A question then arises as to whether the institution of such a policy is an unfair labor practice in violation of $\S 8(\mathrm{a})(3)$ of the National Labor Relations Act, ${ }^{2}$ which forbids an employer "by discrimination in regard to hire and tenure of employment ... to encourage or discourage membership in any labor organization. . .."

In Olin Mathieson Chemical Corp. $v . N L R B,{ }^{3}$ the employer, subsequent to the termination of an economic strike, altered its seniority policy so as to subordinate the rights of returning strikers to those of the workers who had remained on the job or had returned to work during the course of the strike. Thereafter, seven employees were laid off in accordance with the superseniority policy although none could have been removed if their pre-strike seniority rights had been retained. The dis-

\footnotetext{
${ }^{1}$ The cases dealing with the problems of reinstatement or discharge of strikers draw a fundamental distinction between "economic" and "unfair labor practice" strikes, a distinction which stems from the language of $\S_{2}(3)$ of the National Labor Relations Act. This section provides: "The term. 'employee' ... shall include any individual whose work has ceased as a consequence of, or in connection with, any current labor dispute or because of any unfair labor practice, and who has not obtained any other regular and substantially equivalent employment...." (emphasis added.) 49 STAT. 450 (1935), 29 U.S.C. \$ $152(3)$ (1952). The term "current labor dispute" is synonomous with "economic strike" and includes any controversy concerning wages, hours and other employment benefits, as distinguished from the "unfair labor practice strike" which is precipitated by alleged violations by an employer of $\S 8$ (a) of the act. The true significance of this distinction is pointed up by the decision of the Supreme Court in NLRB ข. Mackay Radio \& Telegraph Co., 304 U.S. 333 (1938). See note ro infra. See also NLRB v. A. Sartorius \& Co., 140 F.2d 203, 206 (2d Cir. 1944).

${ }^{2} 49$ STAT. 452 (1935), 29 U.S.C. \& 158 (a) (3) (1952).

3232 F.2d 158 (4th Cir. 1956), cert. granted, 352 U.S. 819 (1956) t2 VA. L. REv. $836(1956)$.
} 
missed employees, through their union representative, filed a complaint with the NLRB alleging that the employer's conduct, in instituting the new seniority system and discharging workers pursuant to that policy, constituted discriminatory conduct of a nature prohibited by Section 8(a) (3) of the NLRA.4 Finding that the employer was thus engaging in an unfair labor practice, the NLRB issued a cease and desist order and ordered reinstatement of the discharged workers with their former seniority rights. On the employer's petition to have the order set aside, the Court of Appeals for the Fourth Circuit, one judge dissenting, ${ }^{5}$ decreed enforcement of the Board's order. ${ }^{6}$

In reaching its decision, the court was forced to distinguish NLRB $v$. Potlatch Forests; Inc., ${ }^{\top}$ in which the Ninth Circuit held that a strike seniority policy which was "advocated . . . before the strike was settled, adopted ... a the time of settlement and ... consistently maintained ... at all times thereafter" (emphasis added) was not a discriminatory practice if adopted for the purpose of protecting and continuing the employer's business during the course of an economic strike. The Supreme Court had ruled several years earlier in NLRB v. Mackay Radio Es Telegraph $C o .^{9}$ that an employer not only could replace striking workers in order to protect his business enterprise but also could offer permanent tenure to replacements as an inducement to accept the positions vacated by the

- The Supreme Court in the leading case of Phelps Dodge Corp. $0 . N L R B, 3 \times 3$ U.S. 177 (1941), held that the discharge of an employee because of participation in strike activities was discrimination within the meaning of $\$ 8(a)(3)$. Similarly, the Seventh Circuit in Polish National Alliance v. NLRB, 136 F.2d 175 (7th Cir. 1943), ruled that the reinstatement of a striker must be unconditional. And see, Republic Steel Corp. $\%$. $N L R B, 114$ F.2d 820, 821 (3rd Cir. 1940), in which the court said: "We think it was the intention of the Board ... to provide that upon reinstatement the striking cmployees were to be treated in all matters involving seniority and continuity of employment as though they had not been absent from work. It follows that the reinstated strikers are entitled to the benefits of Republic's vacation plan for the year in which they are reinstated and all subsequent years upon a basis of continuity of service computed as though they had been actually at work during the entire period [of the strike]. ..."

232 F,2d at 162 . Circuit Judge Soper dissented on the ground that the majority holding was in "direct conflict" with the decision of the Ninth Circuit in NLRB $v$. Potlatch Forests, Inc., 189 F.2d 82 (9th Cir. 1951). See note 11 infra.

'In addition to a violation of $\$ 8(a)$ (3) the court found that "Olin's superseniority policy is in conflict with Section 13 of the Act, providing that 'Nothing in this Act, except as specifically provided for herein, shall be construed so as either to interfere with or impede or diminish in any way the right to strike...' '." [49 STAT. 457 (1935), 29 U.S.C. $\S 163(1952)]$. 232 F.2d at 160 . Incidental to the holding on the question of the employer's strike seniority policy, the NLRB and the Fourth Circuit found that the company had refused to bargain collectively as required by $\$ \S 8(\mathrm{a})(\mathrm{s})$ and (1) of the NLRA. 232 F.2d at 162 .

189 F.2d 82 (gth Cir. 1951).

189 F.2d at 86 .

304 U.S. 333 (1938). 
strikers. ${ }^{10}$.The Fourth Circuit recognized Potlatch as a logical extension of the Mackay doctrine on the ground that since a granting of permanent tenure would preclude even the reinstatement of a replaced striker in his pre-strike position, an additional offer of seniority privileges would seem to impose no further hardship upon the striking employee. In Olin Mathieson, however, the strike seniority policy was not instituted in order to induce strikers and/or new workers to cross the picket line to keep the plant in operation. Rather, the alteration of seniority status occurred after the strike had terminated, motivated, as the court found, by a desire to penalize the reinstated strikers. ${ }^{11}$ Thus, the promise of

30 "Nor was it an unfair labor practice to replace the striking employees with others in an effort to carry on the business. Although $\S 13 \ldots$ provides, Nothing in this Act shall be construed so as to interfere with our impede or diminish in any way the right to strike,' it does not follow that an employer, guilty of no act denounced by the statute, has lost the right to protect and continue his business by supplying places left vacant by strikers. And he is not bound to discharge those hired to fill the places of strikers, upon the election of the latter to resume their employment, in order to create places for them. The assurance by respondent [Mackay] to those who accepted employment during the strike that if they so desired their places might be permanent was not an unfair labor practice nor was it such to reinstate only so many of the strikers as there were vacant places to be filled." NLRB v. Mackay Radio \& Telegraph Co., 304 U.S. 333, 345 (1938). The Mackay doctrine is limited to what the Court termed a "current labor dispute" ( 304 U.S. at 344 ) which is the equivalent of the more commonly used phrase "economic strike." In addition, the words "guilty of no act denounced by the statute," as employed by the Court in the excerpt from its opinion set forth above, indicate that the permissibility of securing permanent replacements does not extend to situations involving "unfair labor practice" strikes within the meaning of the statute.

It should be noted that the Court's decision raises the question as to whether an offer of permanent tenure must be limited to those situations in which replacements would otherwise be unwilling to accept positions. For, in the Mackay case itself, the replacements were secured from other offices of the employer, and it was not clearly shown that the offer of tenure was put forward as an inducement to replacements. 304 U.S. at $33 \dot{8}$.

"But the situation before us is quite different. The strike was over, the strikers had returned to work. ... Olin, after the strike, when there was no necessity for such action to keep its plant in operation, promulgated its superseniority policy in favor of the so-called 'loyal employees' and against those who returned to work after the strike had failed and was over. Olin was clearly penalizing the strikers for exercising their right to strike and was thereby clearly discouraging any exercise of this right in the future." 232 F.2d at 161 . Cf. NLRB v. Sandy Hill Iron \& Brass Works, 165 F.2d 660 (2d Cir. 1947), in which the employer was found to have discriminated against returning strikers by instituting a strike seniority policy. In that case, the court reached its decision on the basis of evidence tending to show that the employer had made several anti-union statements, thus manifesting a discriminatory motive for his conduct.

While there can be little doubt as to the validity of the result reached by the Fourth Circuit in Olin Mathieson, an examination of the facts in the Potlatch case, supra note 7 , reveals an almost indistinguishable situation, thus lending support to the conclusion expressed by Judge Soper in dissent. See note 5 supra. In the latter case, the strike terminated on October 13,1947 and the strike seniority policy was imposed on October 14. Seniority was not offered as an inducement to replacements. Rather, the employer's plan was adopted after the strike had ended, just as was done by the employer in Olin Mathieson. Consequently, commentators, in their discussion of the Potlatch holding, were 
seniority to non-strikers constituted an unlawful discrimination against those employees who had exercised their statutory right to strike.

The Fourth Circuit in the Olin Mathieson decision implies that where replacements, necessary for the preservation of a business, can be obtained only by an offer of seniority over returning strikers, and are so obtained, the institution of a strike seniority policy is justified..$^{12} \mathrm{Un}$ fortunately, the facility with which the court was able to distinguish the Potlatch decision and, thus, find the commission of an unfair labor practice in Olin Mathieson renders unnecessary a judicial determination of the validity of a strike seniority policy per se. An analysis of this broader problem, however, suggests that such a policy, regardless of the time when instituted, would be discriminatory in nature.

Since a striking worker, during the course of a strike, retains his identity as an "employee" within the meaning of the NLRA," he is still entitled to those protections which the act affords. ${ }^{14}$ Thus, until such time as the dispute is settled, an employee who participates in a strike

prone to treat the decision unfavorably, employing reasoning similar to that of the Fourth Circuit in the instant case. See Notes, 4 STAN. L. REV. 151 (1951); 100 U. OF PA. L. ReV. 287 (1951); 6 RUTGers L. ReV. 470 (1952); 30 Texas L. ReV. 776 (1952); 9 WASH. \& LEE L. REV. 115 (1952).

The soundness of the Potlatch decision is open to question on another ground. Compare the statement of the Ninth Circuit that 'the 'discrimination' between replacements and strikers is not an unfair labor practice despite a tendency to discourage union actioities. ..." (189 F.2d at 86) (emphasis added) with the words of the Supreme Court: "Thus an employer's protestation that he did not intend to encourage or discourage must be unavailing where a natural conseguence of his action was stuch encouragement or discouragement." Radio Officers' Union of Cominercial Telegraphers Union v. NLRB, 347 U.S. I7, 45 (1954) (emphasis added.)

12. "Olin, after the strike, when there was no necessity for sucls action to keep its plant in operation, promulgated its superseniority policy. .." 232 F.2d at 161 (emphasis added.) Clearly, the implication here is that a strike seniority policy would have been viewed as valid by the court had the employer offered the seniority privileges as an inducement to replacements.

${ }_{13}$ The statutory defiuition as found in $\S_{2}(3)$ of the act is set forth in note I supra.

14 These protections are stated in the form of negative prohibitions against certain conduct by employers and are found in $\S 8(a)$ of the NLRA.

"Section 8. (a) It shall be an unfair labor practice for an employer-

(x) to interfere with, restrain, or coerce employees in the exercise of the rights guaranteed in section 7 ;

(2) to dominate or interfere with the formation or administration of any labor organization or contribute financial or other support to it. ...

(3) by discrimination in regard to hire or tenure of employment or any term or condition of employment to encourage or discourage membership in any labor organization.....

(4) to discharge or otherwise discriminate against an employee because he has filed charges or given testimony under this Act;

(5) to refuse to bargain collectively with the representatives of his employees. ..." 49 STAT. 452 (1935), 29 U.S.C. \$ 158 (1952). 
cannot be discriminated against "in regard to hire and tenure of employment"; and the Olin Mathieson decision makes it equally clear that the striker who returns to his job following the settlement of the strike cannot be treated unfairly. ${ }^{15}$ While, upon superficial examination, the decision of the Supreme Court in the Mackay case would seem to declare an exception to this rule by permitting a striking worker to be permanently replaced, the termination of a strike strips the replaced striker of his "employee" characteristics and, thus, abrogates his standing to claim statutory protection from the type of discriminatory discharge allegedly practiced by the employer in refusing to reinstate him. ${ }^{16}$ On the other hand, the reinstated striker who has constantly maintained his "employee" status cannot be deprived of those benefits which had accrued to him prior to the calling of the strike. Rather, upon resuming his duties, he is entitled to be restored to his former position with all its attendant privileges. $^{17}$ For, to grant seniority rights to a newly hired strike replacement or a non-striking worker at the expense of a striking employee who returns to his job is to afford benefits to certain employees solely on the basis of their refusal to join in a strike and, at the same time, to deprive other employees of these same benefits solely on the basis of their willingness to participate in a strike. ${ }^{18}$ Clearly, such a

\footnotetext{
Is See note I I supra.

${ }^{10}$ It is this rationale which underlies the decision in the Mackay case, notes 9 and 10 supra.

${ }^{17}$ If a striker has not been replaced within the permissible limits of the Mackay case, supra note 9, he is entitled to reinstatement. Home Beneficial Life Insurance Co. v. NLRB, 159 F.2d 280 (4th Cir. 1947), cert. denied, 332 U.S. 758 (1947); NLRB v. Poultrymen's Service Corp., 138 F.2d 204, 211 (3rd Cir. 1943); Firth Carpet Co. v. NLRB, 129 F.2d 633, 636 (2d Cir. 1942). And such reinstatement must be unconditional. Polish National Alliance v. NLRB, 136 F.2d 175 (7th Cir. 1943); Republic Steel Corp. v. NLRB, I I4 F.2d 820 (3rd Cir. 1940); NLRB v. Star Publishing Co., 97 F.2d 465 (9th Cir. 1938) (These three cases were distinguished in Potlatch, "supra note 7 , on the ground that they involved unfair labor practice strikes as opposed to economic strikes); J \& H Clasgens Co., 56 N.L.R.B. 898 (1944); Indiana Desk Co., 56 N.L.R.B. 76 (1944); St. Marys Sewer Pipe Co., 54 N.L.R.B. 1226 (1944); Wallingford Steel Co., 53 N.L.R.B. 404 (1943); Republic Creosoting Co., 19 N.L.R.B. 267 (1940). But cf. Wilson E Co., Inc. v. NLRB, 120 F.2d 913 (7th Cir. 1941), in which an employer's offer of conditional reinstatement was upheld since the activities of the striking employees were unlawful and, therefore, deprived them of their statutory protection.

${ }^{18}$ The National Labor Relations Board has announced its view toward strike seniority. plans such as that initiated in Olin Mathieson. In its-handling of the Potlatch case, supra note 7, prior to its being appealed to the Ninth Circuit, the Board said as follows: "The aspect of the Return-to-Work Policy' most pertinent here is the division of the Respondent's employees, for purposes of determining seniority upon a reduction in force, into two classes-one, composed of those who had crossed the Union's picket line during the strike; the other, made up of those who remained out on strike during its entire course. Employees in the first class were granted the benefit of a form of superseniority
} 
practice is discriminatory to the extent that it penalizes an employee for availing himself of his right to strike as guaranteed by Section 7 of the NLRA. ${ }^{19}$

Moreover, it has been suggested that this conclusion as to the invalidity of a strike seniority policy is equally applicable to any situation in which an employer subordinates "continuous service credits" of striking employees in deference to the credits of non-strikers or replacements. Thus, a denial of an accrual of vacation and pension benefits to the striker, while permitting an accrual of these same benefits to the nonstriker, would, by analogy to the strike seniority scheme, constitute an unfair labor practice. ${ }^{20}$ In short, an employer has but two alternatives. First, he may secure a permanent replacement for the worker who has elected to participate in the strike; or, second, he may restore the striker to his former position with his pre-strike status in relation to other employees. For, any other course of action would be tantamount to a classification of employees predicated upon their participation in strike activities.

-later styled by the Respondent as 'strike seniority.' Employees in the second class suffered, concomitantly, an impairment of their prestrike relative job retention rights. ...

"[W] $[W e r e$, as in this case, places are in fact available for the returning strikers, and they are actually restored to their former jobs at the termination of the strike, the Mackay Radio doctrine cannot be construed to justify as nondiscriminatory their 'partial reinstatement' ....

"There can be no doubt . . . that a seniority policy which classifies employees according to whether they had worked during a strike, or had not, to the detriment of the relative seniority standings of those who had not, discriminatorily and illegally impairs the employment relationship of those who had exercised their right under the Act to engage in concerted activities." Potlatch Forests, Inc., 87 N.L.R.B. $1193,1201,1209$, 1210 (1949). See also, Precision Castings Co., Inc. 48 N.L.R.B. 870, 879 (1943); Paper, Calmenson and Co., 26 N.L.R.B. 553, 557 (1940) (dictum).

${ }^{10}$ This section of the act provides: "Employees shall have the right to self-organization, to form, join, or assist labor organizations, to bargain collectively through representatives of their own choosing, and to engage in other concerted activities for the purpose of collective bargaining or other mutual aid or protection. . . " 49 STAT. 452 (1935), 29 U.S.C. \& 157 (1952).

${ }^{20}$ "I would go further and find that the tolling of the continuous service credits of the striking employees with respect to the accrual of vacation and pension benefits likewrise constituted discrimination violative of the Act." General Electric Co., 80 N.L.R.B. 5 10, 514 (1948) (Member Murdock, dissenting in part).

The majority of the Board in the General Electric case asserted that "while it is true that non-strikers were compensated by the accrual of vacation and retirement benefits, as well as by money wages, for the period of the strike even though they did no actual work, we do not regard this as discriminatory against the strikers" (emphnsis added.) 80 N.L.R.B. at 511-513. However, both Mr. Murdock and the majority of the members agreed, as to the employer's strike seniority plan, that "except to the extent that a striker may be replaced during an economic strike, his employment relationship cannot otherwise be severed or impaired because of his strike activity." 8o N.L:R:B. at 5,13 . 
Furthermore, an extension of the Mackay doctrine to permit an offering of seniority rights and other benefits as an inducement to strike replacements would virtually nullify the effectiveness of the strike as a collective bargaining device. ${ }^{21}$ For, an inducement to replacements which includes promises not only of permanent job security but also of employment benefits superior to those enjoyed by other employees would require a proportionate increase in union strength to offset the increased incentive to outsiders. ${ }^{22}$ Thus, the economic strike is rendered obviously less effective as a means of exerting pressure on management unless strike replacements are either unavailable, or, being available, are dissuaded from accepting the employer's offer because of the relative power of the striking labor organization.

Accordingly, any inducement to replacements which would afford them employment benefits superior to those of reinstated strikers is not only violative of Section 8(a)(3) of the NLRA but also fails of support from a policy standpoint to the extent that public policy demands the preservation of the economic strike in the collective bargaining process. Therefore, the institution of a "strike seniority" plan must be viewed as an unwarranted extension of the Mackay doctrine-a device which could readily destroy the balance of power in labor-management relations.

\footnotetext{
${ }^{2 x}$ An employee would be highly reluctant to relinquish his position temporarily, knowing that, even should his job be available following settlement of the strike, he would be one of the first to be released in the event of a lay-off. Admittedly, this same element of strike deterrence is inherent in the granting of permanent tenure to replacements, as approved in the Mackay case (supra note 9), and yet two practical considerations suggests that deterrent factors are present there in a lesser degree than in an offer of seniority. For, an employee might be willing to incur the risk of losing his job if he knows that there is a possibility that someone other than himself could easily be the one replaced; in contrast, the same employee would hesitate before joining in a strike if he knew that, in addition to the possible loss of his job, his assured status upon reinstatement would be comparatively worthless because of seniority rights.

One writer, however, has suggested that a strike seniority policy would have no deterrent effect upon strike participation since the possible loss of jobs under Mackay is "a far graver risk than loss of seniority." Note, roo U. OF PA. L. REv. 287, 289 (1951). If the loss of job and the loss of seniority are viewed independently, this assertion is obviously correct. Yet an offer to replacements of seniority must necessarily be coupled with an offer of permanent tenure, since, absent the latter offer, the striking employee is entitied to reinstatment. (See cases cited in note 17 , supra.) It is this double-barreled offer which increases the degree of strike deterrence.

${ }^{22}$ See Note, 4 Stan. L. Rev. I 5 I (195i).
} 